\title{
Systemic sensitivity to corticosteroids in smokers with asthma
}

\author{
E. Livingston*, R. Chaudhuri*, A.D. McMahon`, I. Fraser", \\ C.P. McSharry ${ }^{\#}$ and N.C. Thomson*
}

ABSTRACT: Cigarette smokers with asthma are insensitive to the therapeutic effects of corticosteroids. It is not known whether this insensitivity to corticosteroids in smokers affects tissue sites beyond the airways.

A total of 75 asthmatic subjects (39 smokers) and 78 healthy controls (30 smokers) were recruited to an observational study. The cutaneous and peripheral blood lymphocyte responses to corticosteroids were measured. The cutaneous vasoconstrictor response to topical beclometasone was measured by applying different concentrations of beclometasone solutions to the skin in a random double-blind manner. The degree of blanching at each concentration was graded after $18 \mathrm{~h}$. The sensitivity of peripheral blood lymphocytes to corticosteroids was assessed by measuring the suppressive effect of dexamethasone on lymphocyte proliferation stimulated by phytohaemagglutinin (PHA).

Total mean \pm SD cutaneous vasoconstrictor response score to beclometasone was reduced in smokers with asthma to $5.39 \pm 3.58$ versus $7.26 \pm 3.05$ in never-smokers with asthma; and in all smokers to $6.47 \pm 3.33$ versus $7.86 \pm 2.81$ in all never-smokers. The sensitivity to corticosteroids of lymphocytes stimulated by PHA was similar between groups.

In conclusion, smokers with asthma have an impaired cutaneous vasoconstrictor response to topical corticosteroids compared with never-smokers with asthma. This finding suggests that the insensitivity to corticosteroids in smokers with asthma affects tissue sites other than the airways.

KEYWORDS: Asthma, corticosteroid insensitivity, cutaneous vasoconstriction, lymphocyte proliferation, smoking

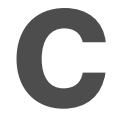
orticosteroids are the most effective antiinflammatory therapy currently available for the treatment of asthma and are recommended in international guidelines [1]. A subgroup of asthmatics do not obtain an adequate therapeutic response to corticosteroids and are termed corticosteroid resistant or insensitive [2]. The causes of corticosteroid-insensitive asthma are considered to be multifactorial, involving both genetic and environmental factors $[2,3]$ including cigarette smoke [4]. Cigarette smokers, compared with never-smokers, with asthma are less sensitive to both inhaled $[5,6]$ and oral corticosteroids [7] as assessed by changes in lung function and asthma symptoms. Smokers with asthma account for $>20 \%$ of adults with asthma [4] and compared with never-smokers experience more severe asthma symptoms [8] and accelerated decline in lung function [9].

It is not known whether smokers with asthma are insensitive to corticosteroids in tissue sites other than the airways. The cutaneous vasoconstrictor response to topical beclometasone [10, 11] and the ability of corticosteroids to inhibit the activation of peripheral blood lymphocytes [12] have been used as an index of systemic sensitivity to corticosteroids. Never-smokers with corticosteroid-insensitive asthma have impaired cutaneous vasoconstrictor responses to corticosteroids [13] and the inhibitory effect of corticosteroids on lymphocyte proliferation is reduced [12]. The present authors hypothesised that smokers with asthma have reduced corticosteroid sensitivity in sites other than the lungs. The aim of the present study was to compare systemic sensitivity to corticosteroids in smokers and never-smokers with and without asthma by assessing the cutaneous vasoconstrictor response to topical beclometasone and the sensitivity of stimulated lymphocytes to corticosteroids.

\section{MATERIALS AND METHODS}

\section{Subjects}

Smoking and never-smoking subjects with and without asthma (white and non-white people) aged 18-60 yrs were recruited from hospital
AFFILIATIONS

Depts of *Respiratory Medicine, and

\# Immunology, University of

Glasgow, and

"Robertson Centre for Biostatistics,

Glasgow, UK.

CORRESPONDENCE

N.C. Thomson

Dept of Respiratory Medicine

Division of Immunology

Infection and Inflammation

University of Glasgow and

Western Infirmary

Glasgow

G11 6NT

UK

Fax: 441412113464

E-mail: n.c.thomson@clinmed.gla.

ac.uk

Received:

October 152005

Accepted after revision:

July 292006

SUPPORT STATEMENT

The current study was funded by the Scottish Council for Postgraduate Medical and Dental Education and the Chief Scientist Office of the Scottish Executive Health Dept (both Edinburgh, UK). 
outpatient clinics and hospital staff, respectively. All participants gave written informed consent and approval for the study was obtained from the West Glasgow Ethics Committee (Glasgow, UK). Asthma was diagnosed by American Thoracic Society (ATS) criteria [14] and all asthmatic subjects had a baseline forced expiratory volume in one second (FEV1) $\leqslant 85 \%$ predicted and a reversibility of FEV1 after nebulised salbutamol of $\geqslant 15 \%$. Exclusion criteria were asthma exacerbations, use of oral corticosteroids or a respiratory tract infection within 4 weeks of inclusion. Healthy volunteers had no history of respiratory disease. Smokers had smoked $\geqslant 10$ pack-yrs and were currently smoking $\geqslant 10$ cigarettes $\cdot$ day $^{-1}$. A total of 35 asthmatic subjects (19 smokers) were also taking long-acting $\beta_{2}$-agonists; three asthmatics (two smokers) were taking leukotriene receptor antagonists.

\section{Study design}

The current authors carried out an observational study in which the cutaneous, peripheral blood lymphocyte and airway responses to corticosteroids were measured. Venous blood was collected for lymphocyte responses, total and specific serum immunoglobulin (Ig)E levels and serum cotinine levels. The cutaneous vasoconstrictor response to topical beclometasone was measured on the same day by applying beclometasone solutions to the skin in a random double-blind manner and assessing the degree of blanching. Sputum induction was performed in subjects with asthma and fractional exhaled nitric oxide $(F \mathrm{eNO})$ and carbon monoxide were measured in all subjects. Subjects with asthma received $40 \mathrm{mg}$ of oral prednisolone daily for 14 days. The end-points used to assess airway corticosteroid sensitivity were change in morning and evening peak expiratory flow (PEF) rate, pre-salbutamol FEV1, validated asthma control score, daily morning and night symptoms and a reduction in the use of rescue inhalers.

\section{Measurements}

Baseline measurements and diary card recordings

Asthma severity was scored at baseline using the ATS asthma impairment score [15] and asthma control was scored at each visit using a validated asthma control questionnaire [16]. Patients maintained a validated home diary card [17] recording morning and night PEF, daytime symptoms (range $0-6$, for increasing severity) and night awakenings (range $0-3$, for increasing severity), use of inhaled rescue medication and study tablet consumption. Compliance was assessed by tablet count. Asthma duration was determined from patient clinical history and hospital records when available. Total serum IgE and specific IgE to house dust mite, grass pollen and cat dander were measured by enzyme linked immunoassay (Unicap; Pharmacia Ltd, Milton Keynes, UK). Total IgE level $>120 \mathrm{IU} \cdot \mathrm{mL}^{-1}$ and specific IgE $>0.35 \mathrm{IU} \cdot \mathrm{mL}^{-1}$ were considered elevated. A subject was defined as nonatopic when specific $\operatorname{IgE}$ to all common allergens was negative [18]. Serum cotinine was measured using an enzyme immunoassay (Cozart Bioscience Ltd, Abingdon, UK) as confirmation of smoking status.

\section{Lung function testing, sputum induction and exhaled gases}

Spirometry was measured with a dry spirometer (Vitalograph Ltd, Buckingham, UK) and the best of three attempts was taken for analysis. FEV1 was measured before and 15 min after administration of $2.5 \mathrm{mg}$ nebulised salbutamol. Sputum induction with $3 \%$ hypertonic saline was performed using a modification of the method described by PIN et al. [19]. The sputum was processed and the dispersed cell total and differential count obtained using the technique described by Popov et al. [20]. Subjects were requested not to smoke for $1 \mathrm{~h}$ prior to their visits and FeNO was measured using a chemiluminescence analyser (LR2000; Logan Research Ltd, Rochester, UK), with a detection limit of $0.1 \mathrm{ppb}$ NO. NO levels were taken from the plateau at the end of exhalation and the mean of triplicate measurements was used as the representative value [21].

\section{Cutaneous vasoconstrictor response to topical beclometasone}

The cutaneous vasoconstrictor response to topical beclometasone was measured as described previously [10], with minor modifications. Beclometasone dipropionate (Sigma-Aldrich, Gillingham, UK) was dissolved in 95\% ethanol to concentrations of $1,3,10,30,100,300$ and $1,000 \mu \mathrm{g} \cdot \mathrm{mL}^{-1}$. A control solution of $95 \%$ ethanol was used. Test sites were outlined on the nondominant flexor forearm by the application of adhesive tape in which 2-cm diameter holes had been cut. Solutions were randomly allocated a letter $(\mathrm{A}-\mathrm{H})$ by staff not involved in the application or reading of the test and solutions applied in order A-H. The test was not unblinded until the completion of the study. The sites were occluded with plastic film to enhance percutaneous absorption of the beclometasone. A tubular bandage (Tubigrip; Seton Healthcare Group, Oldham, UK) was applied to attenuate any changes in ambient temperature. After $18 \mathrm{~h}$, the tape and film were removed and the degree of blanching assessed after a further $1 \mathrm{~h}$. The test sites were examined in standard lighting conditions and given a blanching score by a single trained observer. Blanching at each concentration was graded according to a four-point scale: $0=$ no blanching; 1 =faint blanching; $2=$ obvious blanching not extending beyond the test site; and $3=$ intense blanching extending over the margin of the test site. The addition of individual concentration scores gave a total score. A high score indicates a high degree of corticosteroid sensitivity.

\section{Lymphocyte proliferation response}

The sensitivity of peripheral blood mononuclear cells (PBMCs) to corticosteroids was assessed in a functional assay as described previously [12]. PBMCs were separated from whole blood using Lymphoprep (Axis-Shield PoC AS, Oslo, Norway). Cells were then resuspended at $1 \times 10^{6}$ lymphocytes $\cdot \mathrm{mL}^{-1}$ in RPMI 1640 medium supplemented with $10 \%$ foetal calf serum, $1.25 \mu \mathrm{g} \cdot \mathrm{mL}^{-1}$ fungizone, $1 \%$ L-glutamine, $100 \mu \mathrm{g} \cdot \mathrm{mL}^{-1}$ penicillin and $100 \mathrm{IU} \cdot \mathrm{mL}^{-1}$ streptomycin. Cell viability was assessed by trypan blue exclusion and was always $>95 \%$. PBMCs were incubated in triplicate at a concentration of $1 \times 10^{5}$ cells $\cdot 100 \mu \mathrm{L}^{-1} \cdot$ well $^{-1}$ in 96-well roundbottomed plates (Iwaki microplates; Bibby Sterilin, Stone, UK). The T-lymphocyte mitogen phytohaemagglutinin (PHA; Biostat Ltd, Stockport, UK) was added to the cultured cells at a concentration of $0.6 \mu \mathrm{g} \cdot$ well $^{-1}$ after pilot studies $(n=21$ patients) had established that the suppressive effect of dexamethasone was almost independent of the amount of PHA used over the range $0.054-0.6 \mu \mathrm{g} \cdot \mathrm{well}^{-1}$. Dexamethasone (Sigma-Aldrich; $10^{-11}-10^{-4} \mathrm{M}$ final concentration) was added and the plates cultured at $37^{\circ} \mathrm{C}$ in a humidified atmosphere 
with $5 \% \mathrm{CO}_{2}$ for $48 \mathrm{~h}$. Cell proliferation was measured by uptake of tritiated thymidine. Results were expressed as counts $\cdot \mathrm{min}^{-1}$. Thymidine incorporation as an index of cell proliferation was compared between PHA-stimulated Tlymphocytes with or without dexamethasone. The percentage suppression at the final concentration of dexamethasone (defined as the maximum inhibition (Imax) for the present study) and the gradient of suppression at all concentrations of dexamethasone were compared between smokers and neversmokers with and without asthma.

\section{Statistical analysis}

Baseline characteristics were compared using Chi-squared tests and Wilcoxon tests. The effect of asthma and smoking upon the total skin-test score was assessed by ANOVA, including a test of interaction between the two factors. The responses to oral prednisolone of smokers versus neversmokers with asthma were assessed by ANCOVA models that adjusted each factor by its baseline measure. For those measurements taken from diary cards, the mean of days 1 and 2 was taken to be the baseline and the mean of days 11-14 was taken to be the response measurement. Spearman rank correlations were used to assess the strength of association between the total skin-test score and the various factors of interest. For each patient separately, the downward slope of the best-fitting line was calculated by linear regression. Lymphocyte proliferation response data are shown graphically as mean \pm SEM for clarity.

\section{RESULTS}

\section{Baseline characteristics}

There were no significant differences in the following: age; duration of asthma; equivalent dose of inhaled beclometasone;
$\%$ pred baseline, pre- and post-bronchodilator FEV1; pre- and post-bronchodilator FEV1/forced vital capacity (FVC) ratio; reversibility (\%) to inhaled salbutamol; ATS asthma impairment score; total IgE levels; and induced sputum percentage macrophage, neutrophil and lymphocyte counts among smokers and never-smokers with asthma (tables 1 and 2). Compared with never-smokers with asthma, the group of smokers with asthma contained fewer male subjects and had the following: lower absolute baseline FEV1; lower absolute reversibility to salbutamol; higher asthma control score; lower percentage testing positive for specific IgEs; and lower FeNO levels (tables 1 and 2). Compared with healthy never-smokers, healthy smokers were older and had lower FEV1 (absolute and $\%$ pred) and lower pre-bronchodilator FEV1/FVC ratios. Smoking history was longer and the serum cotinine level was lower in asthmatic smokers versus healthy smokers (table 1).

\section{Cutaneous vasoconstrictor response to topical beclometasone}

There was a significant difference in the mean $\pm S D$ total cutaneous vasoconstrictor response score between smokers $(5.39 \pm 3.58)$ and never-smokers $(7.26 \pm 3.05)$ with asthma $(p=0.023$; fig. 1$)$; between all smokers $(6.47 \pm 3.33)$ and all never-smokers $(7.86 \pm 2.81 ; \mathrm{p}=0.006)$; and between all asthmatics $(6.29 \pm 3.44)$ and all controls $(8.13 \pm 2.50 ; \mathrm{p}<0.001)$. There was no difference between smoking $(7.83 \pm 2.42)$ and never-smoking $(8.33 \pm 2.56)$ controls $(p=0.228$; fig. 1$)$. When adjusted for each other's effects, asthma $(p<0.001)$ and smoking $(p=0.017)$ are both independently associated with the cutaneous vasoconstrictor response. The mean (95\% confidence interval (CI)) reduction for asthmatics after adjustment for smoking was $-1.70(-2.66--0.73)$. Similarly, the mean

\section{TABLE 1 Baseline demography of asthmatic subjects and healthy controls}

\begin{tabular}{|c|c|c|c|c|c|c|}
\hline & Smokers & Never-smokers & p-value & Smokers & Never-smokers & p-value \\
\hline Subjects $n$ & 39 & 36 & & 30 & 48 & \\
\hline Age yrs & $47.4 \pm 7.4$ & $45.1 \pm 10.9$ & 0.42 & $39.9 \pm 8.6$ & $35.2 \pm 8.0$ & 0.029 \\
\hline Male $n$ & 20 & 29 & 0.008 & 10 & 17 & 0.85 \\
\hline Cigarettes $\cdot$ day $^{-1}$ & $22.6 \pm 7.5^{\star}$ & & & $19.3 \pm 7.1$ & & \\
\hline Smoking history yrs & $30.6 \pm 7.2^{\star \star \star}$ & & & $23.3 \pm 8.6$ & & \\
\hline Equivalent dose of inhaled beclometasone $\mu \mathrm{g}$ & $997 \pm 905$ & $631 \pm 646$ & 0.11 & & & \\
\hline FEV 1 L & $1.95 \pm 0.70$ & $2.26 \pm 0.77$ & 0.045 & $2.84 \pm 0.81$ & $3.35 \pm 0.93$ & 0.014 \\
\hline FEV $1 \%$ pred & $63.3 \pm 13.9$ & $63.6 \pm 17.5$ & 0.70 & $93.4 \pm 12.5$ & $99.7 \pm 13.9$ & 0.039 \\
\hline FEV1 post-salbutamol \% pred & $77.5 \pm 5.5$ & $82.6 \pm 6.4$ & 0.44 & & & \\
\hline Reversibility to salbutamol $\mathrm{mL}$ & $426 \pm 236$ & $549 \pm 269$ & 0.014 & & & \\
\hline ATS impairment score & $5.1 \pm 1.9$ & $5.2 \pm 1.9$ & 0.829 & & & \\
\hline Asthma control score & $2.66 \pm 1.08$ & $1.67 \pm 0.83$ & $<0.001$ & & & \\
\hline
\end{tabular}

Data are presented as mean \pm SD, unless otherwise stated. FEV1: forced expiratory volume in one second; \% pred: \% predicted; FVC: forced vital capacity; ATS: American Thoracic Society. *: $p<0.05$, smokers with asthma versus healthy smokers; ***: $p<0.001$, smokers with asthma versus healthy smokers. 
TABLE 2 Allergy levels, serum cotinine, exhaled gases and induced sputum cell counts at baseline in asthmatic subjects and healthy controls

\begin{tabular}{|c|c|c|c|c|c|c|}
\hline & \multicolumn{3}{|c|}{ Asthmatic } & \multicolumn{3}{|c|}{ Healthy controls } \\
\hline & Smokers & Never-smokers & $p$-value & Smokers & Never-smokers & $p$-value \\
\hline Total IgE IU $\cdot \mathrm{mL}^{-1}$ & $87(41-239)$ & $138(60-590)$ & 0.12 & $47(13-74)$ & $32(14-111)$ & 0.82 \\
\hline Specific IgE positive \% & 62 & 91 & 0.004 & 29 & 46 & 0.13 \\
\hline Serum cotinine $\mathbf{n g} \cdot \mathrm{mL}^{-1}$ & $304(131-375)^{*}$ & $2.6(2-3)$ & $<0.001$ & $366(310-421)$ & $2.6(2.3-3.8)$ & $<0.001$ \\
\hline Exhaled NO ppb & $5.1(2.6-7.8)$ & $18.2(12.5-28.6)$ & $<0.001$ & $4.3(2.9-8.1)$ & $7.4(5.6-8.7)$ & 0.006 \\
\hline \multicolumn{7}{|l|}{ Induced sputum cell counts } \\
\hline Macrophages \% & $50(24-67)$ & $51(26-67)$ & 0.93 & & & \\
\hline Neutrophils \% & $42(23-66)$ & $31(13-44)$ & 0.07 & & & \\
\hline Eosinophils \% & $1.0(0.5-2.7)$ & $2.0(0.5-5.5)$ & 0.51 & & & \\
\hline Lymphocytes \% & $1.7(1-2.6)$ & $2.5(0.9-4)$ & 0.61 & & & \\
\hline
\end{tabular}

Data are presented as median (interquartile range), unless otherwise stated. Ig: immunoglobulin; CO: carbon monoxide; NO: nitric oxide. *: p<0.05, asthmatic versus healthy smokers.

(95\% CI) reduction for smoking after adjustment for asthma was $-1.18(-2.15--0.21)$. However, there is no evidence of synergy between the two variables (test of interaction, $p=0.162$ ).

\section{Lymphocyte proliferation response}

Dexamethasone had a concentration-dependent inhibitory effect on the proliferative response to PHA, which was similar in smokers compared with never-smokers, in asthma and in healthy controls (fig. 2). The mean $\pm S D$ Imax was similar between smokers with asthma $(50.3 \pm 26.5)$ compared with never-smokers with asthma $(56 \pm 25.9)$ and in healthy controls who were smokers $(60.8 \pm 21.1)$ compared with never-smokers $(50.4 \pm 27.4$; comparing all four groups $p=0.29)$. The gradients of suppression at all concentrations of dexamethasone were similar in the four groups $(\mathrm{p}=0.44)$.

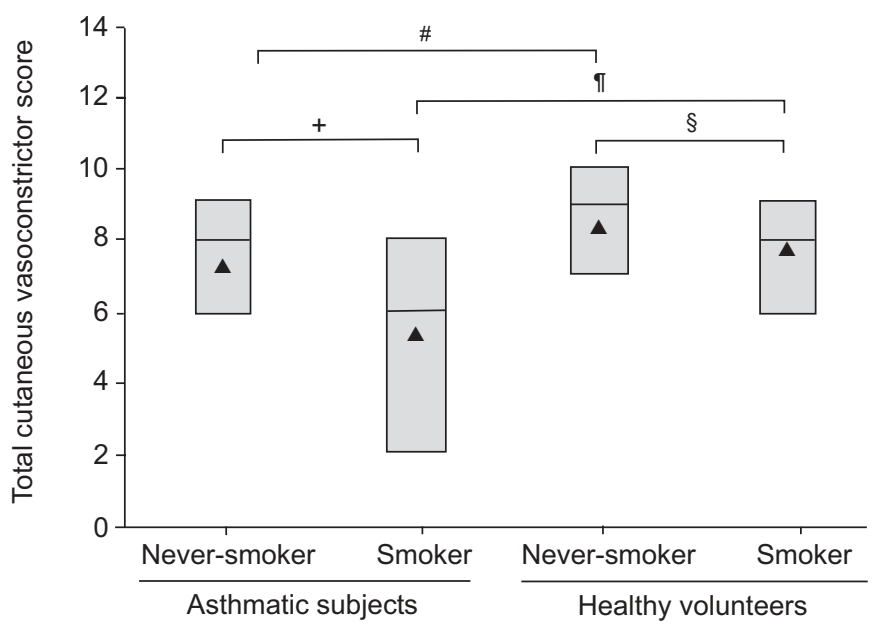

FIGURE 1. Cutaneous vasoconstrictor response to topical beclometasone in asthmatic subjects and healthy controls according to smoking status. interquartile range; —: median; $\mathbf{\Lambda}$ : mean. ${ }^{*}: p=0.091 ;{ }^{\circ}: p=0.003 ;{ }^{+}: p=0.023$; s: $p=0.224$.

\section{Airway response to oral prednisolone}

After administration of high-dose oral corticosteroids, there was a significant improvement in mean $(95 \% \mathrm{CI})$ morning PEF $(26.2$ (2.5-50); $\mathrm{p}=0.031)$, daytime symptoms $(-2.3(-4--0.4) ; \mathrm{p}=0.016)$, asthma control score $(-0.9(-1.4--0.4) ; \mathrm{p}=0.001)$ and rescue medication use $(-0.8(-1.5--0.1) ; \mathrm{p}=0.029)$ and a fall in FeNO (3.2 $(0.1-6.4) ; \mathrm{p}=0.043)$ in never-smokers with asthma compared with smokers with asthma. There was no significant difference in the change in other end-points between the two groups (table 3).

\section{Relationships between cutaneous vasoconstrictor response and baseline measurements}

An increased number of cigarettes smoked per day was associated with a lower total skin-test score $(r=-0.41 ; p=0.010)$, hence increased resistance to corticosteroids. The cutaneous vasoconstrictor response of the whole asthmatic population correlated negatively with the dose of beclometasone $(r=-0.38$; $\mathrm{p}<0.001)$ and asthma control score $(\mathrm{r}=-0.41 ; \mathrm{p}<0.001)$, but there was no correlation with age $(\mathrm{r}=-0.175 ; \mathrm{p}=0.139)$, duration of asthma $(r=-0.08 ; p=0.491)$, asthma severity score $(r=-0.17$; $\mathrm{p}=0.154)$ or total $\operatorname{IgE}(\mathrm{r}=-0.108 ; \mathrm{p}=0.408)$.

\section{DISCUSSION}

The present study has demonstrated that the cutaneous vasoconstrictor response to topical beclometasone is reduced in smokers with asthma compared with never-smokers with asthma and smokers without asthma. These findings suggest, for the first time, that corticosteroid insensitivity in smokers with asthma may be more generalised, affecting tissue sites other than the airways.

The cutaneous vasoconstrictor response to topical beclometasone $[10,11]$ has been used as a screening test to determine the relative anti-inflammatory potency of corticosteroids [22] and as an index of systemic sensitivity to corticosteroids [13]. More objective methods of detecting glucocorticoid-induced skin blanching have been compared with the visual scoring system, 

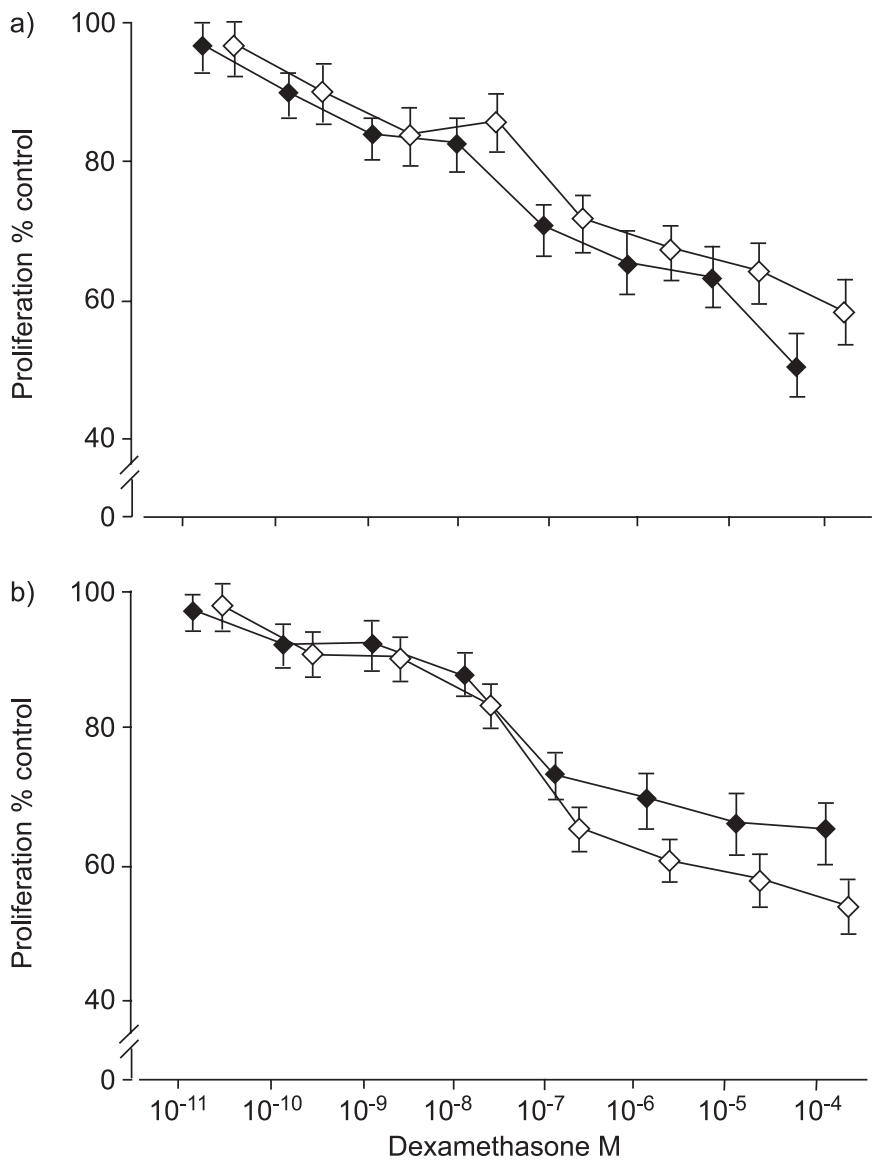

FIGURE 2. Inhibition of phytohaemagglutinin-induced proliferation of peripheral blood T-lymphocytes by dexamethasone $\left(10^{-11}-10^{-4} \mathrm{M}\right)$ from a) subjects with asthma and b) healthy controls. $\bullet$ : smokers; $\diamond$ : never-smokers. Data are presented as mean \pm SEM proliferation in the presence of dexamethasone expressed as a percentage of that obtained without dexamethasone.

but the human eye has been found to be the most sensitive tool to measure dermal blanching [11]. The present authors found that smoking and asthma were independently associated with an impaired cutaneous vasoconstrictor response to topical beclometasone. These findings suggest that smoking and asthma acted in an additive manner to impair cutaneous vasoconstrictor responses. The reason(s) for the reduced cutaneous vasoconstrictor response in smokers with asthma is not clear. If chronic cigarette smoking were to alter the structure or function of skin microvasculature then this might influence the cutaneous vasoconstrictor response to corticosteroids. However, dermal thickness and elasticity of the forearm of smokers are similar to never-smokers [23] as is the cutaneous vasodilator response to intradermal histamine [24]. The dosage of inhaled corticosteroids, age, duration of asthma and severity score were similar between the smokers with asthma and the never-smokers with asthma, despite the former group showing impaired skin responses. The cutaneous vasoconstrictor response is inhibited by glucocorticoid receptor antagonist [25] and correlates with glucocorticoid receptor affinity [22]; the intensity of blanching is potentiated by inhibitors of the local metabolism of cortisol [26]. These findings suggest that the cutaneous vasoconstrictor response is likely to be mediated by glucocorticoid receptors. The negative correlation between the cutaneous vasoconstrictor response and the number of cigarettes smoked per day strengthens the evidence that smoking impairs the response to corticosteroids. It is unclear why asthma should be independently associated with an impaired cutaneous vasoconstrictor response to topical beclometasone. Corticosteroid use is associated with the downregulation of glucocorticoid receptors $[27,28]$ and, as most of the asthmatics were on a moderate dose of inhaled corticosteroids, this may be one explanation of why asthma appeared to be an independent risk factor for an impaired response.

The mechanisms by which corticosteroids cause vasoconstriction may involve inhibition in the uptake of the vasoconstrictor noradrenaline at nerve endings in the skin [29]. Exposure of human skin vasculature to nicotine potentiates noradrenalineinduced skin vasoconstriction [30], but whether nicotine or other constituents of cigarette smoke influence the vasoconstrictor response to corticosteroids is not known. The in vivo sensitivity to topical budesonide of healthy subjects is influenced by glucocorticoid receptor polymorphisms [31]. The glucocorticoid receptor $\alpha: \beta$ ratio is reduced in the PBMCs of cigarette smokers [32] and similar changes might affect glucocorticoid receptors in the skin. Other possible mechanisms of cigarette smoke-induced corticosteroid resistance implicated in other tissues [4], including reduced histone deacetylase (HDAC) activity [33], might be relevant to the skin. HDAC activity has shown to be reduced in patients with asthma [34], chronic obstructive pulmonary disease (COPD) [35] and in subjects who smoke [33]. A preliminary report suggests that HDAC activity is reduced in bronchial biopsies from asthmatic smokers compared with healthy smokers and asthmatic nonsmokers [36]. If similar changes in HDAC activity are found in the skin, this may explain the current findings. Taken together, the current findings suggest that corticosteroid insensitivity in smokers with asthma affects not only the airways but is also a systemic effect, as shown by the reduced, cutaneous vasoconstrictor response in smokers with asthma.

Cigarette smoking has been reported to increase [37] and to decrease [38] lymphocyte proliferation. This anomaly has been partly resolved in animal models by showing that acute tobacco smoke exposure or administration of nicotine is stimulatory for lymphocyte proliferation, whereas chronic exposure is inhibitory $[39,40]$. A similar, approximately linear, dose-dependent level of sensitivity to corticosteroids was found in PHA-stimulated peripheral blood lymphocytes from smokers with asthma compared with never-smokers with asthma. This, in contrast to the impaired cutaneous vasoconstrictor response to topical beclometasone and reduced airway response to prednisolone in the former group, suggests variation in tissue sensitivity to corticosteroids in smokers with asthma. The reason(s) for the different tissue sensitivity in smokers is not known, but a lack of correlation between different tests of tissue sensitivity to corticosteroids has been reported previously in healthy volunteers [41]. As the lymphocyte proliferation test is performed ex vivo, it is possible that any effect of cigarette smoking on lymphocyte function may no longer be present. However, PBMCs from smokers have shown a reduced HDAC activity [33] and altered cytokine levels [42] in vitro. 
TABLE 3 Response of lung function, symptoms, asthma control score and exhaled gases to high-dose ${ }^{\#}$ oral prednisolone in never-smokers with asthma and smokers with asthma

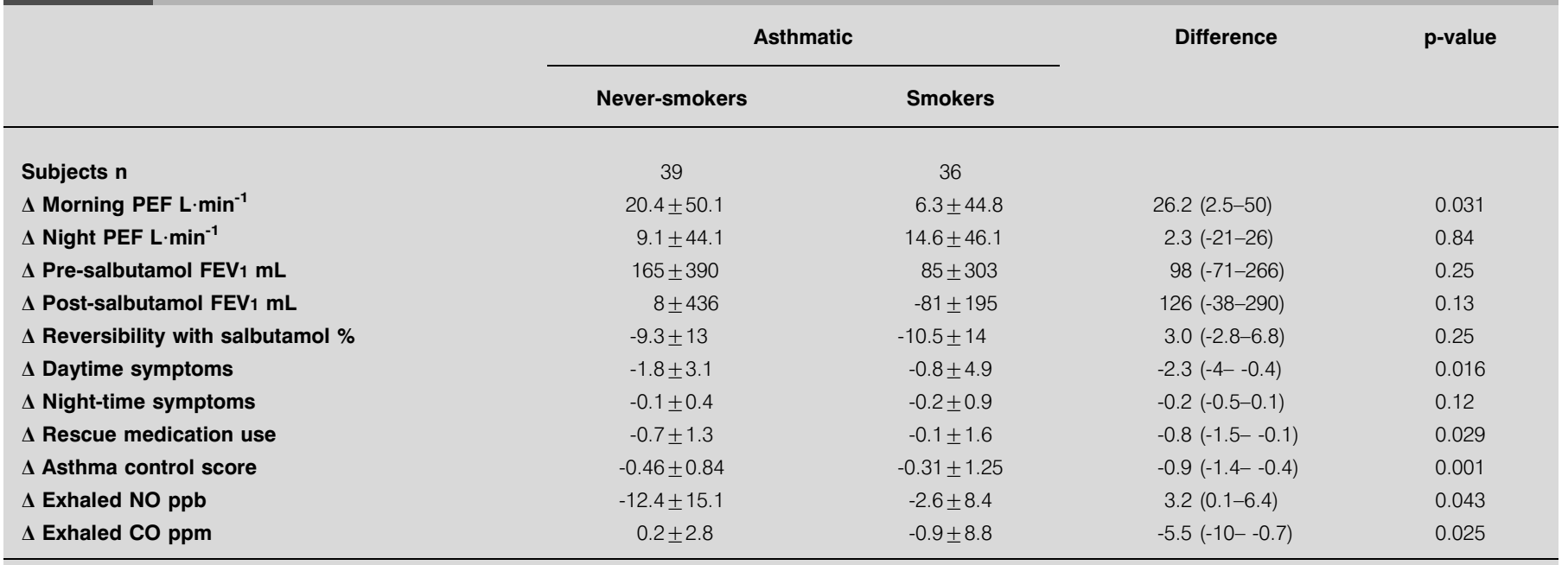

Data are presented as mean \pm SD and mean ( $95 \%$ confidence interval), unless otherwise stated. All variables have been analysed by ANCOVA. $\Delta$ : change; PEF: peak expiratory flow; FEV1: forced expiratory volume in one second; NO: nitric oxide; CO: carbon monoxide. \#: 40 mg for 2 weeks.

The results of the present study demonstrate a reduced response to oral corticosteroids in smokers with asthma compared with never-smokers, measured by morning PEF, rescue medication use, daytime symptoms and asthma control score, but not by FEV1. This result was similar, but not identical, to findings in previous studies using inhaled fluticasone [6] or oral prednisolone [7] compared with a placebo. The current study was designed differently, with a single arm of treatment, and included smokers and neversmokers with baseline lung function more severe than in the present authors' previous studies.

Smoking is widely accepted as the major cause of COPD. It can often be difficult to differentiate smokers with asthma from those with COPD. However, the current authors are confident that the smokers in the present study had asthma rather than COPD. The smokers with asthma fulfilled the diagnostic criteria for asthma, had a mean age of $47 \mathrm{yrs}$ and had been symptomatic from their mid-20s, which would be rare in patients with COPD. The asthmatic smokers had a postsalbutamol FEV1 of $>75 \%$ pred, higher than expected in symptomatic patients with COPD, and had reversibility to salbutamol of $\geqslant 15 \%$. In a previous study, it was found that induced sputum neutrophil counts were elevated in smokers with asthma compared with nonsmokers with mild asthma [43]. In the current study, there was a trend towards a raised neutrophil count in the smoking asthmatics compared to the neversmokers $(p=0.070)$, but both groups had more severe disease.

In conclusion, the results of the current study show that smokers with asthma have an impaired cutaneous vasoconstrictor response to topical corticosteroids compared with never-smokers with asthma. This finding suggests that the insensitivity to corticosteroids in smokers with asthma affects tissue sites other than the airways. This not only has implications for smokers with asthma, but may also be important in other corticosteroid-sensitive inflammatory conditions.

\section{ACKNOWLEDGEMENTS}

The authors are grateful to K. Lattka, Medical Illustration Dept, Gartnavel General Hospital, Glasgow, UK, for assistance with the figures.

\section{REFERENCES}

1 Global Initiative for Asthma. Global strategy for asthma management and prevention. NHLBI/WHO Workshop report 2002: NIH Publication No. 02-3659. Bethesda, National Institutes of Health, 2002.

2 Leung DY, Bloom JW. Update on glucocorticoid action and resistance. J Allergy Clin Immunol 2003; 111: 3-22.

3 Barnes PJ. Corticosteroid resistance in airway disease. Proc Am Thorac Society 2004; 1: 264-268.

4 Thomson NC, Chaudhuri R, Livingston E. Asthma and cigarette smoking. Eur Respir J 2004; 24: 822-833.

5 Tomlinson JEM, McMahon AD, Chaudhuri R, Thompson JM, Wood SF, Thomson NC. Efficacy of low and high dose inhaled corticosteroids in smokers versus non-smokers with mild asthma. Thorax 2005; 60: 282-287.

6 Chalmers GW, MacLeod KJ, Little SA, Thomson LJ, McSharry CP, Thomson NC. Influence of cigarette smoking on inhaled corticosteroid treatment in mild asthma. Thorax 2002; 57: 1-5.

7 Chaudhuri R, Livingston E, McMahon A, et al. Cigarette smoking impairs the therapeutic response to oral corticosteroids. Am J Respir Crit Care Med 2003; 168: 1308-1311.

8 Siroux V, Pin I, Oryszcyn MP, Le Moual N, Kauffman F. Relationships of active smoking to asthma and asthma severity in the EGEA study. Epidemiological Study on the Genetics and Environment of Asthma. Eur Respir J 2000; 15 : 470-477.

9 Lange P, Parner J, Vestbo J, Schnohr P, Jensen G. A 15 year follow-up study of ventilatory function in adults with asthma. N Engl J Med 1998; 339: 1194-1200. 
10 McKenzie AW, Stoughton RB. Method for comparing percutaneous absorption of steroids. Arch Dermatol 1962; 86: 608-610.

11 Noon JP, Evans CE, Haynes WG, Webb DJ, Walker BR. A comparison of techniques to assess skin blanching following the topical application of glucocorticoids. $\mathrm{Br}$ J Dermatol 1996; 134: 837-842.

12 Corrigan CJ, Brown PH, Barnes NC, et al. Glucocorticoid resistance in asthma: glucocorticoid pharmacokinetics, glucocorticoid receptor characteristics, and inhibition of peripheral blood $\mathrm{T}$ cell proliferation by glucocorticoids in vitro. Am Rev Respir Dis 1991; 144: 1016-1025.

13 Brown PH, Teelucksingh S, Matusiewicz SP, Greening AP, Crompton GK, Edwards CR. Cutaneous vasoconstrictor response to glucocorticoids in asthma. Lancet 1991; 337: 576-580.

14 American Thoracic Society. Standards for the diagnosis and care of patients with chronic obstructive pulmonary disease (COPD) and asthma. Am Rev Respir Dis 1987; 136: 225-244.

15 American Thoracic Society. Medical Section of the American Lung Association. Guidelines for the evaluation of impairment/disability in patients with asthma. Am Rev Respir Dis 1993; 147: 1056-1061.

16 Juniper EF, O’Byrne PM, Guyatt GH, Ferrie PJ, King DR. Development and validation of a questionnaire to measure asthma control. Eur Respir J 1999; 14: 902-907.

17 Santanello NC, Barber BL, Reiss TF, Friedman BS, Juniper EF, Zhang L. Measurement characteristics of two asthma symptom diary scales for use in clinical trials. Eur Respir J 1997; 10: 646-651.

18 Johansson SG, Hourihane JO, Bousquet J, et al. A revised nomenclature for allergy: an EAACI position statement from the EAACI nomenclature task force. Allergy 2001; 56: 813-849.

19 Pin I, Gibson PG, Kolendowicz R, et al. Use of induced sputum cell counts to investigate airway inflammation in asthma. Thorax 1992; 47: 25-29.

20 Popov T, Gottschalk R, Kolendowicz R, Dolovich J, Powers P, Hargreave FE. The evaluation of a cell dispersion method of sputum examination. Clin Exp Allergy 1994; 24: 778-783.

21 Kharitonov S, Alving K, Barnes PJ. Exhaled and nasal nitric oxide measurements: recommendations. The European Respiratory Society Task Force. Eur Respir J 1997; 10: 1683-1693.

22 Johnson M. Development of fluticasone propionate and comparison with other inhaled corticosteroids. J Allergy Clin Immunol 1998; 101: S434-S439.

23 Knuutinen A, Kokkonen N, Risteli J, et al. Smoking affects collagen synthesis and extracellular matrix turnover in human skin. Br J Dermatol 2002; 146: 588-594.

24 Mills CM, Hill SA, Marks R. Altered inflammatory responses in smokers. BMJ 1993; 307: 911.

25 Gaillard RC, Poffet D, Riondel AM, Saurat JH. RU 486 inhibits peripheral effects of glucocorticoids in humans. J Clin Endocrinol Metab 1985; 61: 1009-1011.

26 Walker BR, Connacher AA, Webb DJ, Edwards CR. Glucocorticoids and blood pressure: a role for the cortisol/cortisone shuttle in the control of vascular tone in man. Clin Sci 1992; 83: 171-178.

27 Sanden S, Tripmacher R, Weltrich R, et al. Glucocorticoid dose dependent downregulation of glucocorticoid receptors in patients with rheumatic disease. I Rheumatol 2000; 27: $1265-1270$.

28 Andersson O, Cassel TN, Gronneberg R, Bronnegard M, Stierna P, Nord M. In vivo modulation of glucocorticoid receptor mRNA by inhaled fluticasone propionate in bronchial mucosa and blood lymphocytes in subjects with mild asthma. J Allergy Clin Immunol 1999; 103: 595-600.

29 Horvath G, Lieb T, Conner GE, Salathe M, Wanner A. Steroid sensitivity of norepinephrine uptake by human bronchial arterial and rabbit aortic smooth muscle cells. Am J Respir Cell Mol Biol 2001; 25: 500-506.

30 Black CE, Huang N, Neligan PC, et al. Effect of nicotine on vasoconstrictor and vasodilator responses in human skin vasculature. Am J Physiol Regul Integr Comp Physiol 2001; 281: R1097-R1104.

31 Panarelli M, Holloway CD, Mulatero P, Fraser R, Kenyon CY. Inhibition of lysozyme synthesis by dexamethasone in human mononuclear leukocytes: an index of glucocorticoid sensitivity. J Clin Endocrinol Metab 1994; 78: 872-877.

32 Livingston E, Darroch CE, Chaudhuri $\mathrm{R}$, et al. Glucocorticoid receptor $\alpha: \beta$ ratio in blood mononuclear cells is reduced in cigarette smokers. J Allergy Clin Immunol 2004; 114: 1475-1478.

33 Ito K, Lim S, Caramori G, Chung KF, Barnes PJ, Adcock IM. Cigarette smoking reduces histone deacetylase 2 expression, enhances cytokine expression, and inhibits glucocorticoid actions in alveolar macrophages. FASEB J 2001; 15: 1110-1112.

34 Ito K, Caramori G, Lim S, et al. Expression and activity of histone deacetylases in human asthmatic airways. Am J Respir Crit Care Med 2002; 166: 392-396.

35 Ito $\mathrm{K}$, Ito $\mathrm{M}$, Elliott $\mathrm{WM}$, et al. Decreased histone deacetylatase activity in chronic obstructive pulmonary disease. N Engl J Med 2005; 352: 1967-1976.

36 Murahidy A, Ito M, Adcock IM, Barnes PJ, Ito K. Reduction in histone deacetylase activity and expression in airways of smoking asthmatics: a mechanism of steroid resistance. Proc Am Thorac Soc 2005; 2: A889.

37 Zeidel A, Beilin B, Yardeni I, Mayburd E, Smirnov G, Bessler H. Immune response in asymptomatic smokers. Acta Anaesthesiol Scand 2002; 46: 959-964.

38 Berntorp K, Ekman M, Berntorp E. Cigarette smoke impairment of human lymphocyte function by inhibition of transglutaminase. J Intern Med 1989; 226: 73-79.

39 Kawashima K, Fujii T. The lymphocytic cholinergic system and its contribution to the regulation of immune activity. Life Sci 2003; 74: 675-696.

40 Singh SP, Kalra R, Puttfarcken P, Kozak A, Tesfaiqzi J, Sopori ML. Acute and chronic nicotine exposures modulate the immune system through different pathways. Toxicol Appl Pharmacol 2000; 164: 65-72.

41 Hearing SD, Norman M, Smyth C, Foy C, Dayan CM. Wide variation in lymphocyte steroid sensitivity among healthy human volunteers. J Clin Endocrinol Metab 1999; 84: 4149-4154.

42 Byron KA, Varigos GA, Wootton AM. IL-4 production is increased in cigarette smokers. Clin Exp Immunol 1994; 95: 333-336.

43 Chalmers GW, MacLeod KJ, Thomson L, Little SA, McSahrry C, Thomson NC. Smoking and airway inflammation in patients with mild asthma. Chest 2001; 120: 1917-1922. 